\title{
Revised Unitary Heat Pump Specification for Military Family Housing
}

William Mulroy Stephen Weber David Didion

U.S. DEPARTMENT OF COMMERCE National Bureau of Standards National Engineering Laboratory Center for Building Technology Gaithersburg, MD 20899

June 1988

Sponsored by:

U.S. Army Corps of Engineers U.S. Department of the Army Washington, DC 20314

Engineering Services and Utility Branch U.S. Department of the Air Force Washington, DC 20330-5000

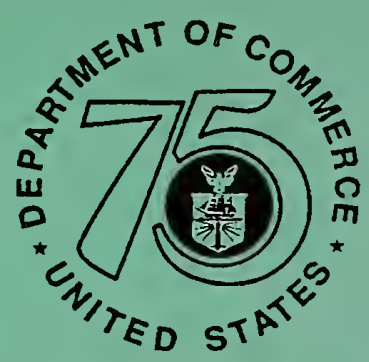

75 Yoars Sumulating America's Progress

Naval Facilities Engineering Command U.S. Department of the Navy Alexandria, Virginia 22332 
เ 
NBSIR 88-3805

REVISED UNITARY HEAT PUMP

SPECIFICATION FOR MILITARY

FAMILY HOUSING

William Mulroy

Stephen Weber

David Didion

U.S. DEPARTMENT OF COMMERCE

National Bureau of Standards

National Engineering Laboratory

Center for Building Technology

Gaithersburg, MD 20899

June 1988

Sponsored by:

U.S. Army Corps of Engineers

U.S. Department of the Army

Washington, DC 20314

Engineering Services and Utility Branch

U.S. Department of the Air Force

Washington, DC 20330-5000

Naval Facilities Engineering Command

U.S. Department of the Navy

Alexandria, Virginia 22332

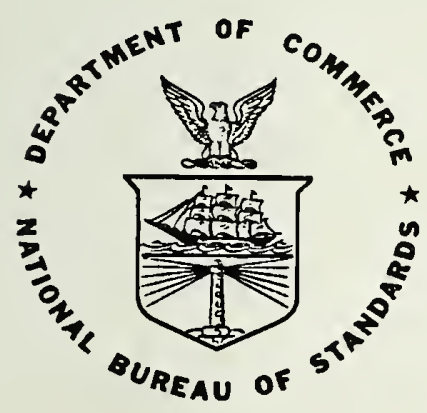

U.S. DEPARTMENT OF COMMERCE, C. William Verity, Secretary

NATIONAL BUREAU OF STANDARDS, Ernest Ambler, Director 

Revised Unitary Heat Pump Specifications for Military Family Housing

\section{ABSTRACT}

The purpose of this report is to revise and update the unitary heat pump specifications developed in 1976* which addressed the requirements for performance, testing, rating, design, safety, serviceability and reliability for the system and components; and conformance conditions. The document is intended for guidance in military procurement and applies to hermetic electrically-driven vapor compression unitary heat pumps of the remote (split) and packaged (integral) types, the air-to-air and water-to-water classes, and sizes from 12,000 to $135,000 \mathrm{Btu} / \mathrm{h}$ for both heating and cooling functions. This report reflects changes in specifications such that the qualified units would be compatible with current available commercial products. It also addresses installation practices and offers a new life cycle costing criterion for competitive selection. It is written in the format of a draft specification.

Key Words: Heating and cooling; military family housing; specifications; unitary heat pump

$*$ NBSIR $76-1029$ 

1. PURPOSE, SCOPE AND CLASSIFICATION

1.1 Purpose

1.2 Scope.

1.3 Classification and Definition

2. REFERENCED SPECIFICATIONS AND STANDARDS . . . . . . . . . . . . . . 3

2.1 American National Standards Institute (ANSI) . . . . . . . . . 3

2.2 Air-Conditioning and Refrigeration Institute (ARI) . . . . . . 3

2.3 American Society of Heating, Refrigerating, and Air Conditioning Engineers, Inc. (ASHRAE) . . . . . . . . . . . 4

2.4 Underwriter's Laboratories, Inc. (UL) . . . . . . . . . . . . 4

2.5 Department of Defense (DoD). . . . . . . . . . . . . . . . . 4

2.6 Air Conditioning Contractors of American (ACCA) . . . . . . . . 5

2.7 American Society for Testing and Materials (ASTM) . . . . . . . 5

2.8 Department of Energy (DoE) . . . . . . . . . . . . . . 5

3. PROCUREMENT GUIDELINES . . . . . . . . . . . . . . . . . . . . . . . 6

3.1 Prerequisite . . . . . . . . . . . . . . . . . 6

3.2 Instructions to Purchaser . . . . . . . . . . . . . . . . . 7

3.3 Selection Criteria . . . . . . . . . . . . . . . . . . . . . 9

3.4 Applicable Standards . . . . . . . . . . . . . . . . . . 9

4. GENERAL REQUIREMENTS FOR EQUIPMENT . . . . . . . . . . . . . . . . . 11

4.1 Description. . . . . . . . . . . . . . . . . . . . . . . 11

4.2 Standards . . . . . . . . . . . . . . . . . . . . . . . 12

4.3 Heat Pump Cooling and Heating Capacity . . . . . . . . . . . . 12

4.4 Operational and Reliability Requirements . . . . . . . . . . . 13

4.5 Supplemental Electric Resistance Heat . . . . . . . . . . . . . 13

4.6 Refrigerant . . . . . . . . . . . . . . . . . . . . . 14

4.7 Indoor Temperature Control . . . . . . . . . . . . . . . . 15

4.8 Defrost. . . . . . . . . . . . . . . . . . . . . 15

4.9 Protective Mechanisms, Controls and Auxiliary Equipment . . . . 16

4.10 Sound Rating . . . . . . . . . . . . . . . . . . . . . . 16

4.11 Hermetic Motor-Compressor Units . . . . . . . . . . . . . . . 16

4.11.1 Thermal Protection . . . . . . . . . . . . . . 17

4.11.2 Current Overload Protection . . . . . . . . . . . . 17

4.11.3 Crankcase Heating . . . . . . . . . . . . . . . . . . . 17

4.11.4 Time Delay Mechanisms . . . . . . . . . . . . . . 18

4.11.5 Liquid Flood-Back . . . . . . . . . . . . . . . . . 18

4.12 Moisture in Refrigerant . . . . . . . . . . . . . . . . . 18

4.13 Strainer . . . . . . . . . . . . . . . . . . . . 18

4.14 Materials in Outdoor Unit . . . . . . . . . . . . . . . . 19

4.15 Air Filters. . . . . . . . . . . . . . . . . . . . . 19

4.16 Water-to-Air Heat Pumps . . . . . . . . . . . . . . . 20 
5. QUALITY ASSURANCE PROGRAMS . . . . . . . . . . . . . . . 21

5.1 Responsibility for Inspection and Examination . . . . . . . . 21

5.2 Tests for Quality Conformance . . . . . . . . . . . . . 21

5.2.1 Capacity Tests . . . . . . . . . . . . . 22

5.2.2. Operational Tests ............. . 22

5.2.3 Reliability Tests . . . . . . . . . . . . . 23

5.3 Sampling for Capacity and Operational Tests . . . . . . . . 23

5.4 Sampling for High Stress Reliability Tests ... . . . . . . . 24

5.5 Sampling for Life Cycle Reliability Tests . . . . . . . . 24

6. PERFORMANCE TESTS . . . . . . . . . . . . . . . 25

6.1 Capacity and Efficiency Tests . . . . . . . . . . . . . 25

6.2 Operational Tests . . . . . . . . . . . . . . . . . 25

6.3 Reliability Tests . . . . . . . . . . . . . . . . 26

6.3.1 High Stress Reliability Tests . . . . . . . . . 27

6.3.1.1 Criteria for Acceptance . . . . . . . . . . . . 27

6.3.1.2 Test Specifications for Air Source Heat Pumps . 29

6.3.1.3 Test Specification for Water Source Heat Pumps. 30

6.3.2 Life Cycle Reliability Tests ............ . 31

6.3.2.1 Criteria for Acceptance . . . . . . . . . . 31

6.3.2.2 Test Specifications . . . . . . . . . . . 33

6.3.3 Corrosion Tests . . . . . . . . . . . . . . 33

6.3.3.1 Salt Spray Test............ . 34

6.3.3.2 Indoor Unit Corrosion Test . . . . . . . 34

6.3.3.3 Criteria for Acceptance......... 35

7. LIFE CYCLE COST . . . . . . . . . . . . . . 36

8. REQUIREMENTS FOR QUALIFIED INSTALLER . . . . . . . . . . . . 41

8.1 Qualification . . . . . . . . . . . . . . . 41

8.2 Guarantee . . . . . . . . . . . . . . . 41 


\section{PURPOSE, SCOPE AND CLASSIFICATION \\ 1.1 Purpose}

The purpose of this specification is to establish, for unitary heat pump equipment; the requirements for performance, testing, rating, design, safety, serviceability and reliability for system and components and conformance conditions. This specification is intended for guidance in military procurement.

\subsection{Scope}

This specification applies to hermetic electrically-driven vapor-compression unitary heat pumps of the types defined in Section 1.3 having suitable heating and cooling capacities for military family housing.

\subsection{Classification and Definition}

The term heat pump, applied to a year-round air conditioning system, denotes a system in which refrigeration equipment is used in such a manner that heat is taken from a heat source and given up to the conditioned space when heating service is desired, and heat is removed from the conditioned space and discharged to a heat sink when cooling and dehumidification are desired. Unitary heat pumps shall be defined as consisting of one or more factory-made assemblies which normally include indoor conditioning coil(s), compressor(s), outdoor coil(s) or water-to-refrigerant heat exchanger and necessary controls to provide both heating and cooling functions. The heating function may be supplemented by electric resistance heaters. Unitary heat pumps within the scope of this specification shall be classified by: 
Physical configuration (Type)

Type I - Remote (split) type - The indoor and outdoor units are separated and remote one from the other.

Type II - Packaged (integral, single) type - The indoor and outdoor units are housed in a single cabinet assembly.

Heat source and sink (Class)

Class A - Air-to-air heat pump - Air is the heat sink and source medium for the outdoor and indoor units.

Class B - Water-to-air heat pump - Water is the heat sink and source medium for the outdoor unit or condenser and chiller. Air is the medium providing conditioned air to spaces.

Size (Capacity at ARI Standard Rating Condition)

Size $1-12,000$ to $65,000 \mathrm{Btu} / \mathrm{h}(3,500$ to 19,000 watts $)$

$\underline{\text { Size } 2}-65,000$ to $135,000 \mathrm{Btu} / \mathrm{h}(19,000$ to 39,600 watts $)$ 


\section{REFERENCED SPECIFICATIONS AND STANDARDS}

The specifications and standards of the issue listed below (including amendments, addenda, and errata), but referred to thereafter by designation only, form a part of this specification to the extent required by the reference thereto:

\subsection{American National Standards Institute(ANSI)}

$\begin{array}{ll}\text { ANSI/ASHRAE } 15-1978 & \text { Safety Code for Mechanical Refrigeration } \\ \text { ANSI/ASHRAE } 34-1978 . & \text { Number Designation of Refrigerants }\end{array}$

\subsection{Air-Conditioning and Refrigeration Institute(ARI)}

210/240-84 Standard for Unitary Air Conditioning and Air

Source Heat Pump Equipment

$240-81$

Air-Source Unitary Heat Pump Equipment

$260-75$

Standard for Application, Installation and

Servicing of Unitary Equipment

$270-84$

Standard for Sound Rating of Outdoor Unitary

Equipment

$275-84$

Standard for Application of Sound-Rated Outdoor

Equipment

320-81

Standard for Water Source Heat Pumps

$325-83$

Standard for Ground Water Source Heat Pumps

$520-78$

Standard for Positive Displacement Refrigerant

Compressors and Condensing Units

$710-80$

Standards for Liquid Line Driers 
2.3 American Society of Heating, Refrigerating, and Air-Conditioning Engineers, Inc. (ASHRAE)

36-72 Methods of Testing for Sound Rating Heating, Refrigerant and Air Conditioning Equipment

37-78 Methods of Testing for Rating Unitary AirConditioning and Heat Pump Equipment

90A-1980 Energy Conservation in New Building Design

116-1984 Methods of Testing for Seasonal Efficiency of Unitary Air Conditioners and Heat Pumps

GRP158 Cooling and Heating Load Calculation Manual

2.4 Underwriter's Laboratories. Inc. (UL)

559 Standard for Safety - Heat Pumps

984 Standard for Safety - Sealed (Hermetic Type) Motor-Compressors

\subsection{Department of Defense (DoD)}

$4270.21-1970$

Guide Specifications for Military Family Housing Air Conditioning, Mechanical Division 15.16a

MIL-H-22547B(YD) Military Specification: Heat Pumps, Heating and Cooling (Unitary) $(8,400$ to $300,000 \mathrm{Btu})$

AFM 88-29 Engineering Weather Data

TM5 - 785

NAVFAC $\mathrm{P}-89$ 


\subsection{Air Conditioning Contractors of America (ACCA)}

Manual $G \quad$ Selection of Distribution System

Manual J Load Calculation for Residential Winter and Summer Air

Conditioning

Manual $0 \quad$ Equipment Selection and System Design Procedures

\subsection{American Society for Testing and Materials (ASTM)}

B117-64 Standard Method of Salt Spray (Fog) Testing

D1654-61 Standard Method of Evaluation of Painted or Coated

Specimens at 100 Percent Relative Humidity

D2247-68(R80) Standard Method for Testing Coated Metal Specimens at 100\%

Relative Humidity

G33-72 Standard Recommended Practice for Recording Data From

Atmospheric Corrosion Tests of Metallic-Coated Steel Specimens

\subsection{Department of Energy (DoE)}

DoE/NBS-0011 TI-59 Program for Calculating the Annual Energy Requirements for Residential Heating and Cooling

DoE/CE-0076 Federal Energy Management Program Life Cycle Cost Manual Update 


\section{PROCUREMENT GUIDELINES}

\subsection{Prerequisite}

Prerequisite to the use of this specification for procurement it is necessary for the purchaser to determine weather data, design heating and cooling loads and the design for air distribution systems of the military residential housing to be equipped with the heat pump equipment obtained under this specification.

- Weather data for outdoor design conditions should be in accordance with Engineering Weather Data Air Force, Army and Navy Manual.

Design sensible heating and sensible and latent cooling loads should be determined in accordance with procedures described in Cooling and Heating Load Calculation Manual (ASHRAE GRP 158) or procedures given in ACCA Manual J, latest edition.

- Air distribution systems should be suitable for both winter heating and summer cooling and should conform to practices established in ACCA Manual G, Manual D and ARI 260 for design, selection and installation of duct system and insulation, and registers and diffusers. Sections of DOD 4270.21 covering requirements for installation of heating and air conditioning equipment and air distribution systems, testing of heating and air conditioning systems, etc., should be used in preparation of project specifications for military family housing. 
If water-to-air heat pumps are to be considered, an adequately proven year-round supply of water should be available. The quality (hardness, acidity, mineral content, gas content, and bacterial count) of the water and its temperature for both winter and summer seasons should be determined and stated in the request for purchase. Also, compatibility with water pollution regulations should be ensured.

\subsection{Instructions to Purchaser}

Items which must be specified by the purchaser of unitary heat pump equipment in the contract or purchase order with reference to the provisions referred to in this specification are as follows:

Required voltage and related electrical characteristics.

Winter and summer design indoor and outdoor conditions and the seasonal heating hours for $5^{\circ} \mathrm{F}\left(2.8^{\circ} \mathrm{C}\right)$ temperature increments as given in the Engineering Weather Data Manual.

Required heating and cooling capacities, in Btu/h (watts), at specified winter and summer design conditions, respectively.

Type and class of heat pump required. Also size and dimension limitations, or other special construction considerations.

- Additional preproduction and/or post production capacity, conformance and/or reliability tests as required and if any or 
all tests are to be waived. In the area of reliability testing, lack of data relating laboratory tests to field performance forces some of the required operating conditions and hours of operation to be somewhat arbitrary. If a manufacturer can demonstrate that he is meeting the intent of the reliability tests with a testing program of his own design (e.g. historical field reliability data), the purchaser may choose to waive the specified reliability tests.

Specific performance data desired in addition to required test data.

- Marginal cost of electricity, present value factor for life cycle costing.

- Minimum external resistance of air distribution system when delivering the rated capacity and air quantity.

- Length of warranty period. Items to be covered by warranty (parts, labor, etc.).

- When water-to-air heat pumps are specified, data covering water quantity available in gallons per minute, summer and winter water temperatures, water source and quality of water will be furnished by the military services.

- For geographical regions of high corrosion potential, such as coastal regions with salt spray exposure, specify salt spray test. 


\section{3 . Selection Criteria}

The unit to be purchased shall be that which meets the purchaser specified procurement guidelines (Section 3.2), the general requirements (Section 4) and quality assurance provisions (Section 5) of this document and which will result in the lowest life cycle cost (Section 7 ).

\subsection{Applicable Standards}

Throughout this document reference is made to applicable current ARI standards. These standards are those which are used for testing and rating for listing in the most recent edition of the appropriate ARI directory of certified products. As this document is being written (April 1988), the current applicable ARI standard for air source heat pumps is 240-81. It is recommended that units covered by ARI 240-81 that are greater than $65,000 \mathrm{Btu} / \mathrm{h}(19,000$ watts $)$ in capacity shall be tested in the same way as those less than $65,000 \mathrm{Btu} / \mathrm{h}(19,000$ watts $)$ in order to provide the necessary data for calculation of local SEER and HSPF values to allow application of the lowest life cycle cost criterion of this standard. This requires the performance of additional "B" cooling steady state and heating mode frost accumulation tests and either performance of cycling tests or use of the default value of $C_{D}$.

At this time ground water source units are rated under ARI 325 and water source heat pumps under ARI 320. It is recommended that rating under ARI 320 be allowed for units which use well water of an approximately constant $70^{\circ} \mathrm{F}\left(21 .^{\circ} \mathrm{C}\right)$ temperature (approximately DoE zones 1 and 2) and that rating under ARI 325 be allowed also for this application and required for all 
other ground water source applications.

As newer Department of Energy approved methods for calculating seasonal efficiency are developed which can be adopted to site particular energy consumption calculations, these should be employed in lieu of the above mentioned standards.

For all other cited documents, the most recent revision shall be used for procurement under this specification. 


\section{GENERAL REQUIREMENTS FOR EQUIPMENT}

\subsection{Description}

Throughout this specification the term "heat pump" will be used interchangeably with the term "unitary heat pump" as defined in Sections 1.2 and 1.3 .

All heat pumps of a given type, class and size to be delivered under a specific contract or purchase order shall be of the same manufacturer and model. Remote (split) type heat pumps shall consist of a complete packaged outdoor unit and a complete packaged indoor unit, on which the capacity, operational, and reliability tests of this document have been performed as a rated, matched set. Precharged factory supplied units and tubing shall be furnished with remote type heat pumps whenever available. Packaged (integral) type heat pumps shall consist of a single factory-assembled sheet-metal casing complete with indoor and outdoor units piped and wired, ready for connection to duct system and electric circuits. Electric resistance heaters may be field installed in either type. The cooling capacity of the system shall not be less than the cooling design load specified in the contract or purchase order. The resistance heating coils shall be capable of handling a minimum of 1008 of the heating design load. Unless otherwise specified, the maximum airflow and minimum external pressure shall be as required in the current applicable ARI standard referenced in section 2.2. Unit components shall be readily accessible for maintenance and service. Certain requirements in this specification, particularly current overload protection, crankcase heating, time delay mechanisms and liquid flood-back protection are included for system 
reliability needs. If a bidder has alternative means to accomplish these functions, the acceptance shall be dependent on proof submitted by the heat pump manufacturer, and acceptable to the contracting officer. This proof shall include written certification that the alternative means satisfy the functional requirements.

\subsection{Standards}

Heat pumps shall conform to current applicable ARI standards, UL 559 and ANSI/ASHRAE 15. Proof shall be submitted showing that the items furnished under this specification conform to such requirements. The listing and labels (together) of the ARI and a nationally recognized safety approval agency for the manufacturer's standard model will be acceptable as sufficient evidence that the items conform to the label-identified standards of these organizations. In lieu of such certification, label or listing, a written certificate from a testing laboratory or agency adequately equipped and competent to perform such services shall be submitted stating that the items have been tested and that the heat pump units and assembled components conform to requirements specified in current applicable ARI standards, UL 559 and ANSI B9.1. Description of test methods shall accompany certificate.

\subsection{Heat Pump Cooling and Heating Capacity}

The heat pump heating and cooling (sensible and latent) capacities shall not be less than that specified for the winter and summer outdoor design conditions of the contract or purchase order when tested in accordance with Section 5.2.1.1. The minimum capacity for the supplemental heaters 
shall be at least equal to the heating load at the winter design outdoor temperature.

The heat pump manufacturer shall state the rated voltage and capacity of supplemental heaters. The heaters shall provide this capacity when tested in accordance with Section 6.1.4. Air source heat pumps shall meet the minimum efficiency requirements of the current ASHRAE Standard 90, or those which may be in effect by the local civilian authority, whichever is more stringent. This criteria is predominate in case of conflict with life cycle cost criteria noted later in this report.

\subsection{Operational and Reliability Requirements}

Heat pumps qualified for delivery under this specification shall meet the operational and reliability criteria of the current applicable ARI standards and shall have been subjected to and successfully passed the operational and reliability tests required in Section 5 of this specification and shall conform to the requirements contained in Section 6 of this specification.

\subsection{Supplemental Electric Resistance Heat}

If supplementary heat is needed to satisfy the heating requirements (see Section 4.3) of this specification, supplemental electric resistance heaters shall be provided and shall be located downstream of the indoor coil. The electric heaters shall be electrically wired in accordance with UL 559 and controlled in one or more steps so that they shall provide sufficient additional heating capacity for building heat demand loads in 
excess of the compression and indoor fan heating capacity. No single step of supplemental heating shall produce a temperature rise in the discharge air greater than $40^{\circ} \mathrm{F}\left(22.2^{\circ} \mathrm{C}\right)$. The heaters shall be controlled by means of outdoor and indoor thermostats interlocked one with the other. The outdoor thermostat, whose operation shall override that of the indoor thermostat, shall prevent the supplementary heaters from operating at outdoor temperatures above $40^{\circ} \mathrm{F}\left(4.4^{\circ} \mathrm{C}\right)$ except as required to offset cooling effect during defrost operation (Section 4.8) or in the case of emergency (e.g., compressor failure). For the heating operation, the indoor thermostat shall operate in at least two steps. The first step shall initiate heat pump operation for heating by compression only. The second step (and additional step(s), if provided) shall control heating provided by the supplemental heaters. The cut-on temperature for the first set of supplemental heaters shall be between $0.5^{\circ} \mathrm{F}\left(.3^{\circ} \mathrm{C}\right)$ and $1.5^{\circ} \mathrm{F}$ $\left(.8^{\circ} \mathrm{C}\right)$ below the cut-on temperature for the compression heating. Additional steps of supplemental heating if required shall be activated for both cut-off and cut-on, respectively in $0.5^{\circ} \mathrm{F}\left(.3^{\circ} \mathrm{C}\right)$ to $1.0^{\circ} \mathrm{F}\left(.6^{\circ} \mathrm{C}\right)$ steps below the first step of supplemental heating by the thermostat. The total operating temperature differential between thermostat cut-on and cut-off of the compression heating control shall not exceed $2^{\circ} \mathrm{F}\left(1.1^{\circ} \mathrm{C}\right)$. All quoted thermostat temperature differentials are as measured at the switch (i.e., switch differential).

\subsection{Refrigerant}

The refrigerant shall be Group I Classification as described in ANSI/ASHRAE 34. The type of refrigerant to be used in the system shall be as specified 
in the contract or purchase order. If not so specified, the refrigerant shall be $\mathrm{R}-22$.

\subsection{Indoor Temperature Control}

Temperature controls for heat pump operation shall be capable of being set to control heating at any temperature at least from $55^{\circ} \mathrm{F}\left(12.8^{\circ} \mathrm{C}\right)$ up and to control cooling at any temperature from at least $85^{\circ} \mathrm{F}\left(29.4^{\circ} \mathrm{C}\right)$ down. The thermostat shall be factory locked to prevent setting below $42^{\circ} \mathrm{F}\left(5.6^{\circ} \mathrm{C}\right)$. When the heat pump system is operating (except during defrost operation), the temperature control shall be capable of regulating the indoor temperature at the thermostat to within $2^{\circ} \mathrm{F}\left(1.1^{\circ} \mathrm{C}\right)$ of the control setting when only compression heating is being provided and to within $3^{\circ} \mathrm{F}\left(1.7^{\circ} \mathrm{C}\right)$ of the control setting when compression and supplemental heating is required. For control of supplemental heat see Section 4.5. The thermostat shall contain or a sub-base shall be provided containing selector switches for COOL-OFF-HEAT and FAN-AUTO-ON.

\subsection{Defrost}

Air-source heat pumps designed to operate with a defrost cycle shall include positive actuation and termination means for defrosting the coils and fins of the outdoor unit automatically with suitable drain provisions to remove condensate and meltage without freeze-up and other malfunctions throughout the entire range of application temperatures. 


\subsection{Protective Mechanisms, Controls and Auxiliary Equipment}

The heat pump system shall contain the necessary components, protective mechanisms, controls and auxiliary equipment for it to meet the requirements and tests set forth in this specification. Safety devices and protective controls shall be used to limit or terminate abnormal operating conditions and shall not be used to control normal heat pump operation. Also refer to Section 4.2 .

\subsection{Sound Rating}

All outdoor unitary heat pump equipment shall be sound rated and tested in accordance with ARI 270 and shall not exceed a sound rating of 8.4 bels for units below $38,000 \mathrm{Btu} / \mathrm{h}(11,100$ watts $), 8.6$ bels for units between 38,000 $\mathrm{Btu} / \mathrm{h}(11,100$ watts $)$ and $65,000 \mathrm{Btu} / \mathrm{h}(19,000$ watts $)$ and 8.8 bels for units between $65,000 \mathrm{Btu} / \mathrm{h}(19,000$ watts $)$ and $135,000 \mathrm{Btu} / \mathrm{h}(39,600$ watts $)$ in capacity as defined in these standards. The ARI label will be acceptable as sufficient evidence of compliance with the test method of ARI 270 . In lieu of such certification or label, a written certificate from a testing agency or laboratory adequately equipped and competent to perform such services shall be submitted stating that the equipment has been tested and conforms to requirements specified in ARI 270 and to the requirements of this specification.

\subsection{Hermetic Motor-Compressor Units}

Hermetic motor-compressor units shall conform to the requirements of UL 984 with regard to construction, performance and testing. The requirements for motor-compressor protection systems of this standard shall also apply in 
addition to the following.

\subsubsection{Thermal Protection}

An internal motor-winding temperature-sensing protection device of the automatic reset type for the compressor motor shall be provided to prevent motor operation under excessive motor winding temperatures. The heat pump compressor manufacturer's recommended maximum average motor winding temperature shall not be exceeded when the heat pump is operating under any of the tests prescribed in ARI 210/240, and in no case shall winding temperature under any of these test conditions exceed $300^{\circ} \mathrm{F}\left(149^{\circ} \mathrm{C}\right)$. The heat pump compressor manufacturer's recommended maximum average motor winding temperature shall be stated in the bid submission.

\subsubsection{Current Overload Protection}

Motor running-current overload protection conforming to the National Electric Code (refer to UL 984), shall be provided for the compressor motor. If manual reset is provided it shall be readily accessible and reset means clearly marked.

\subsubsection{Crankcase Heating}

Means shall be provided for heating the compressor crankcase of units with outdoor compressors which equalize crankcase pressure to suction pressure, so that liquid slugging as a result of liquid foaming under compressor starting conditions is prevented. Crankcase heaters either external or internal (except for motor windings used as heaters) shall be readily replaceable from the exterior without breaking the refrigerant seal. 


\subsubsection{Time Delay Mechanism}

The motor protection system shall contain a device or means that delays operation of the compressor motor for a period of at least three but not more than six minutes after compressor operation is called for when shut-down for any reason, inadvertent or otherwise has occurred. (Note: This is needed to diversify startup loads in housing areas after power interruption and to guard against short cycling of individual units.)

\subsubsection{Liquid Flood-Back}

A means shall be provided for protecting the compressor of air source units from liquid flood-back, under all design conditions of operation, including defrost. Properly designed and sized accumulators or a sufficiently large oil sump within the hermetic shell will satisfy this requirement. Accumulators must provide for return of oil to the compressor.

\subsection{Moisture in Refrigerant}

The system shall contain a filter-drier conforming to ARI 710. Refrigerant piping shall be circuited such that backwashing of the filter-drier by reversal of refrigerant flow does not occur unless the filter is designed for bidirectional operation. The moisture content in the refrigerant shall not exceed $60 \mathrm{ppm}$ at time of heat pump installation and $30 \mathrm{ppm}$ at conclusion of the Reliability Tests (see Section 6.3).

\subsection{Strainer}

If the heat pump system uses capillary tubes as a refrigerant expansion device, a strainer shall be installed in the line ahead of the capillary 
tube assembly capable of stopping passage of scale and other particulate matter of minor dimension greater than 208 of the bore size of the smallest tube.

\subsection{Materials in Outdoor Unit}

The materials of which the components in the outdoor unit are fabricated and the method of fabrication shall be such that when a heat pump system is subjected to the Reliability Tests (Section 6.3) of this specification, it shall pass the tests and retain its physical and structural integrity. Construction methods shall be utilized which minimize or eliminate the galvanic effect. Coils and fins of the outdoor coil shall be corrosion resistant or treated to resist corrosion. Coils, fins and fan shall be protected from physical damage by means of a suitable grill or other means which do not lower the airflow through the coil enough to prevent the specified performance of the system.

\subsection{Air Filters}

Air filters mounted on the air return to the indoor unit shall be furnished. The air filter installation shall preferably be integral with the indoor unit and if mounted remotely in the house duct system, the duct must be leak tight to the unit. The air filter shall be readily accessible for removal from the indoor unit for cleaning or replacement after residential installation. The air filter installation shall have no unplugged holes or cracks allowing air to bypass the filter prior to reaching the indoor coil. 


\subsection{Water-to-Air Heat Pumps}

Water-to-air heat pumps shall be capable of meeting the following performance requirements.

1. The water temperature leaving the condenser during cooling operation shall not exceed the maximum water temperature recommended by the manufacturer.

2. The water temperature leaving the water-to-refrigerant heat exchanger during heating operation shall not be less than $40^{\circ} \mathrm{F}$ $\left(4.4^{\circ} \mathrm{C}\right)$ for open loop systems and the manufacturer's recommended temperature with the manufacturer's recommended circulating fluid (brine) for closed loop systems.

3. A low pressure cut-out device with a manually reset lockout or a freezestat shall be installed so as to prevent freezing during the heating operation.

4. Construction and/or piping for water-to-refrigerant heat exchangers of open loop systems shall include provision for isolation and access valving for the purposes of chemical cleaning or physical access for mechanical cleaning of the water side of heat exchange surfaces. Water piping and valving may be installed. 


\section{QUALITY ASSURANCE PROCEDURES}

\subsection{Responsibility for Inspection and Examination}

The contractor (supplier) shall be responsible for the fulfillment of all inspection requirements as specified herein. The contractor shall be responsible for insuring that the components of the system, even though manufactured by a secondary supplier, are tested, and examined, and are satisfactory for inclusion in the heat pump system. The supplier shall also be responsible for the fulfillment of requirements of the referenced applicable documents for any component of the heat pump system. Unless otherwise specified in the contract or purchase order, the Government (purchaser) reserves the right to perform any of the inspections to determine if the requirements set forth in Section 4 are fulfilled. If the Government so desires it may contract this responsibility to any qualified commercial or Government laboratory.

\subsection{Tests for Quality Conformance}

Three types of tests required by this specification shall be performed, or shall have been performed for each type, class, model and size to be supplied in the contract or purchase order; namely, 1) capacity, 2) operational and 3) reliability tests. The data required shall be obtained from tests described in Section 6, with regard to all inspections and capacity, operational and reliability tests. The Government reserves the right to make any or all inspections and tests necessary in addition to those required in the contract or purchase order to assure conformance with specification requirements at any time prior to final acceptance. If such additional testing indicates failure to conform, the cost of the unit 
or component tested and the cost of testing will be borne by the supplier. If such additional testing indicates conformance, the cost of the unit or component tested and the cost of testing will be borne by the Government.

\subsubsection{Capacity Tests}

The supplier shall provide manufacturer's heating and cooling data which shall be obtained in accordance with the current applicable ARI standard and certified as required in paragraph 4.2. Certified performance data shall include capacity and power input at the standard rating condition and the application rating condition as described in the current applicable ARI standard.

For the heating and cooling capacity tests above, if, in the contract or purchase order an air system distribution resistance or airflow different from the values listed in the current applicable ARI standard is specified, the performance data required shall be adjusted accordingly.

Manufacturer's performance data is data based on tests of which the accuracy is attested to by the unit manufacturer. Certified performance data is data of which the accuracy is attested to either by an independent testing laboratory or by a certification program such as that of ARI.

\subsubsection{Operational Tests}

The heat pump system shall operate satisfactorily under standard and maximum operating conditions (refer to Section 4.4). Heat pumps scheduled for delivery under this specification shall meet all requirements of the 
current applicable ARI standard. The ARI label and listing in the current ARI directory will be accepted as evidence of meeting this requirement. In lieu of such certification and label, a written certificate from a testing agency or laboratory adequately equipped and competent to perform such services shall be submitted stating that the equipment conforms to requirements specified in the current applicable ARI standard.

\subsubsection{Reliability Tests}

The heat pump shall be subjected by the manufacturer to either the high stress or the life cycle reliability tests listed in Section 6.3 of this specification (unless waived by the purchaser) and shall conform to the listed requirements, and shall perform without damage to any part except as permitted herein. Reliability test data shall be made available to the purchaser by the manufacturer if requested.

\subsection{Sampling for Capacity and Operational Tests}

Unless otherwise required in the contract or purchase order, the heat pump type, class, model and size to be provided for delivery shall have its certified data for all listed capacity tests and operational tests and shall satisfactorily conform to all test requirements. Units which are identical but not necessarily the same physical units may be used for the capacity and operational tests and the reliability tests. The heat pump tested as representative of each type, model and size shall pass all tests described in Section 5.2, and as specified under Sections 6.1 and 6.2. 


\subsection{Sampling for High Stress Reliability Tests}

If the high stress reliability test option is chosen, at least one heat pump of each type, class, model or closely related models to be provided under this contract and picked at random shall have been subjected to and successfully passed the reliability tests (Section 6.3.1) conducted in accordance with the following plan. If there are no failures in this first specimen, the type, class, model and size will be considered satisfactory with respect to the reliability tests. If there are not more than two failures, three additional specimens picked at random shall undergo a test for conformance to all listed reliability requirements. If there is not more than one failure of the same kind, or not more than three failures altogether from that toral of four specimens tested, the lot will be considered satisfactory with respect to the reliability tests. If there are two or more failures of the same kind, or four or more failures altogether from the total of four specimens tested, all heat pumps of that type, class, model and size shall be rejected. Sampling under this option applies to each type, class, model or worst case condition of closely related models, and worst size condition within models which are to be provided under this contract. A failure shall be considered to be an inability to meet any of the criteria for acceptance of 6.3 .1 .1 .

\subsection{Sampling for Life Cycle Reliability Tests}

Sampling for the life cycle reliability test option shall be at random and shall be sufficiently large as to be statistically significant as defined in Section 6.3.2.1. Sampling under this option applies to each type, 
class, model or worst case condition of closely related models, and worst size condition within models which are to be provided under this contract.

\section{PERFORMANCE TESTS}

\subsection{Capacity and Efficiency Tests}

This section describes tests of heat pumps for determination of capacity and coefficient of performance. Testing procedures shall, where applicable, be as described in the current applicable ASHRAE test procedure for all sizes of heat pumps procured under this document. Unless otherwise specified, test conditions shall be as set forth in the current applicable ARI standard. At rating and application conditions, the efficiency of the heat pump for heating and cooling shall be calculated from the test data in a manner as defined by the current applicable ARI standard. This determination shall act as input to the Life Cycle Cost procedure described in Section 7 of this document.

The heating capacity of the supplemental heaters shall be determined by the measurement of the electrical power usage of the supplemental heater(s). The electrical power usage shall be measured at specified voltage and at room temperature of $70 \mathrm{~F}(21.1 \mathrm{C})$ with suitable instrumentation accurate to within 2 percent of the measured value. The test data shall be used to determine compliance with Sections 4.5 and 4.3 .

\subsection{Operational Tests}

As stated in Section 5.2.2, required operational tests are the following tests described in the Performance Requirements of the current applicable ARI standard: 
1. Maximum Operating Condition Test

2. Voltage Tolerance Test

3. Low Temperature Operation Test (Cooling)

4. Insulation Efficiency Test (Cooling)

5. Condensate Disposal Test (Cooling)

\subsection{Reliability Tests}

For the purpose of this specification, reliability tests for air source heat pumps will be considered in two separate programs: (1) high stress tests and (2) life cycle tests. The high stress test program is intended to take the system beyond its normal operating limits to ensure that there are adequate safety devices that will shut the system down in order to protect the essential, more expensive components (i.e., compressor). The life cycle tests are designed to have the unit operate under simulated field conditions near or slightly beyond the worst expected climatic conditions for an extended period of time. The contractor must submit the manufacturer's data that proves the specific model or a closely related model to that being offered has successfully completed either one or the other of these programs (high stress or life cycle) as defined in the following sections.

In addition to either of these test programs the purchaser may specify one or both of the corrosion tests described in Section 6.3.3; depending on the climatic conditions of the installation site. 


\subsubsection{High Stress Reliability Tests}

Temperature tolerances for the reliability tests shall be as specified in performance requirements of ARI 210/240. Voltage tolerances shall be \pm 3 volts. All of these tests shall be performed without the indoor thermostat in the system or with the thermostat shunted to call for continuous operation. All manual-reset operating, protective, and limit controls/devices shall be reactivated within 30 minutes following trip-out or similar operation throughout each test. Supplemental heaters shall not be operated in any of the reliability tests. Indoor unit air inlet temperature shall be held in the range from $70^{\circ} \mathrm{F}\left(21.1^{\circ} \mathrm{C}\right)$ to $80^{\circ} \mathrm{F}\left(26.7^{\circ} \mathrm{C}\right)$ for tests. For all tests, the portions of the tests that call for unit operation imply continuous compressor operation except as controlled by protective/limit devices. High stress reliability tests for water source heat pumps shall be performed with water, not freezing inhibited brine, as the circulating fluid.

\subsubsection{Criteria for Acceptance}

As applicable, the following requirements must be met for acceptance:

1. No impairing damage shall occur to any component during these tests.

2. The temperature of the oil sump remote from the suction line inlet to the compressor shall at no time during steady-state operation be less than $40^{\circ} \mathrm{F}\left(22.2^{\circ} \mathrm{C}\right)$ warmer than that of the suction line within 6 inches $(.152 \mathrm{~m})$ of the compressor shell. During the off cycle this temperature difference may decrease 
to $10^{\circ} \mathrm{F}\left(5.6^{\circ} \mathrm{C}\right)$. On start up this temperature difference must constantly increase toward its steady state value.

3. The temperature of the discharge line within six inches $(.15 \mathrm{~m})$ of the compressor shall at no time during steady state operation be less than $20^{\circ} \mathrm{F}\left(11.1^{\circ} \mathrm{C}\right)$ warmer than the saturation temperature corresponding to the discharge pressure for more than 5 minutes. Thermocouples shall be used for these measurements, shall be physically bonded to the respective sufaces (including at least one inch $(.025 \mathrm{~m})$ of the leads) and shall be insulated from ambient conditions .

4. No audible knocking or hammering of mechanical parts shall occur in excess of that occurring in normal continuous operation at standard rating conditions in the current applicable ARI standard.

5. Trip-out of operating, protective, and limit controls/devices shall not constitute a failure.

6. Average motor winding temperature shall not exceed $300^{\circ} \mathrm{F}\left(149^{\circ} \mathrm{C}\right)$ at any time during any of the reliability tests. Use of a Seely bridge is recommended for measurement of the average winding temperature while the motor is running.

7. Discharge refrigerant line temperature within 6 inches $(.15 \mathrm{~m})$ of the compressor shall not exceed $250^{\circ} \mathrm{F}\left(121^{\circ} \mathrm{C}\right)$ during the 
reliability tests.

8. Upon completion of the reliability tests, the moisture content of the refrigerant shall be determined and the moisture content shall not exceed $30 \mathrm{ppm}$ with filter drier included in the system.

\subsubsection{Test Specifications for Air Source Heat Pumps}

1. Heating and cooling test

Voltage as specified in the contract or purchase order

Outdoor air dry-bulb temperature $70^{\circ} \mathrm{F}\left(21.1^{\circ} \mathrm{C}\right)$ to $80^{\circ} \mathrm{F}\left(26.7^{\circ} \mathrm{C}\right)$

Indoor air dry-bulb temperature $70^{\circ} \mathrm{F}\left(21.1^{\circ} \mathrm{C}\right)$ to $80^{\circ} \mathrm{F}\left(26.7^{\circ} \mathrm{C}\right)$

$100 \%$ operation - $50 \%$ cooling and $50 \%$ heating

Cycle reversal every hour

48 hours total test duration

2. High temperature test (cooling)

Voltage $90 \%$ of specified

Outdoor air dry-bulb temperature $130^{\circ} \mathrm{F}\left(54.4^{\circ} \mathrm{C}\right)$ to $140^{\circ} \mathrm{F}\left(60^{\circ} \mathrm{C}\right)$

Indoor air dry-bulb temperature $70^{\circ} \mathrm{F}\left(21.1^{\circ} \mathrm{C}\right)$ to $80^{\circ} \mathrm{F}\left(26.7^{\circ} \mathrm{C}\right)$

1008 unit operation

24 hours total test duration

3. Low temperature test (heating)

Voltage 1108 of specified

Outdoor air dry-bulb temperature the higher of the lowest recorded

temperature for the region or the unit cut-off temperature

Indoor dry-bulb temperature $70^{\circ} \mathrm{F}\left(21.1^{\circ} \mathrm{C}\right)$ to $80^{\circ} \mathrm{F}\left(26.7^{\circ} \mathrm{C}\right)$

Operation: Off 24 hours, On 8 hours, off 24 hours, On 8 hours 64 hours total test duration

4. Blocked air filter test (cooling)

Voltage as specified

Outdoor air dry-bulb temperature $95^{\circ} \mathrm{F}\left(35^{\circ} \mathrm{C}\right)$ to $105^{\circ} \mathrm{F}\left(40.6^{\circ} \mathrm{C}\right)$

Indoor dry-bulb temperature $70^{\circ} \mathrm{F}\left(21.1^{\circ} \mathrm{C}\right)$ to $80^{\circ} \mathrm{F}\left(26.7^{\circ} \mathrm{C}\right)$

$100 \%$ unit operation: 12 hours at $50 \%$ of normal airflow across indoor coil, 12 hours with no airflow across indoor coil (indoor fan inoperative and filter face blocked for this test)

24 hours total test duration 


\section{Low refrigerant charge test (cooling)}

Voltage as specified

Outdoor air dry-bulb temperature $95^{\circ} \mathrm{F}\left(35^{\circ} \mathrm{C}\right)$

Indoor air dry-bulb temperature $70 \mathrm{~F}\left(21.1^{\circ} \mathrm{C}\right)$ to $80^{\circ} \mathrm{F}\left(26.7^{\circ} \mathrm{C}\right)$

$50 \%$ of manufacturer's recommended refrigerant charge

$100 \%$ unit operation

24 hours total test duration

6. Low refrigerant charge test (heating)

Conditions same as 5 above, except outdoor air temperature $20^{\circ} \mathrm{F}$ $\left(-6.7^{\circ} \mathrm{C}\right)$ to $35^{\circ} \mathrm{F}\left(1.7^{\circ} \mathrm{C}\right)$

\subsubsection{Test Specifications for Water Source Heat Pumps}

1. Heating and cooling test

Voltage as specified in the contract or purchase order

Entering Water temperature $70^{\circ} \mathrm{F}\left(21.1^{\circ} \mathrm{C}\right)$ to $50^{\circ} \mathrm{F}\left(10.0^{\circ} \mathrm{C}\right)$

Indoor air dry-bulb temperature $70^{\circ} \mathrm{F}\left(21.1^{\circ} \mathrm{C}\right)$ to $80^{\circ} \mathrm{F}\left(26.7^{\circ} \mathrm{C}\right)$

$100 \%$ operation - $50 \%$ cooling and $50 \%$ heating

Cycle reversal every hour

48 hours total test duration

2. High temperature test (cooling)

Voltage 908 of specified

Entering Water temperature $85^{\circ} \mathrm{F}\left(29.4^{\circ} \mathrm{C}\right)$ to $95^{\circ} \mathrm{F}\left(35.0^{\circ} \mathrm{C}\right)$

Indoor air dry-bulb temperature $70^{\circ} \mathrm{F}\left(21.1^{\circ} \mathrm{C}\right)$ to $80^{\circ} \mathrm{F}\left(26.7^{\circ} \mathrm{C}\right)$

100 z unit operation

24 hours total test duration

3. Low temperature test (heating)

Voltage $110 \%$ of specified

Outdoor air dry-bulb temperature for split system units the higher of the lowest recorded temperature for the region or the unit cut-off temperature

Entering water temperature $36^{\circ} \mathrm{F}\left(2.2^{\circ} \mathrm{C}\right)$ to $32^{\circ} \mathrm{F}\left(0^{\circ} \mathrm{C}\right)$

Indoor dry-bulb temperature $70^{\circ} \mathrm{F}\left(21.1^{\circ} \mathrm{C}\right)$ to $80^{\circ} \mathrm{F}\left(26.7^{\circ} \mathrm{C}\right)$

Operation: Off 24 hours, On 8 hours, Off 24 hours, On 8 hours 64 hours total test duration 


\section{Blocked air filter test (cooling)}

Voltage as specified

Entering water temperature $65^{\circ} \mathrm{F}\left(18.3^{\circ} \mathrm{C}\right)$ to $75^{\circ} \mathrm{F}\left(23.9^{\circ} \mathrm{C}\right)$

Indoor dry-bulb temperature $70^{\circ} \mathrm{F}\left(21.1^{\circ} \mathrm{C}\right)$ to $80^{\circ} \mathrm{F}\left(26.7^{\circ} \mathrm{C}\right)$

$100 \%$ unit operation: 12 hours at $50 \%$ of normal airflow across indoor coil, 12 hours with no airflow across indoor coil (indoor fan

inoperative and filter face blocked for this test)

24 hours total test duration

\section{Low refrigerant charge test (cooling)}

Voltage as specified

Entering water temperature $65^{\circ} \mathrm{F}\left(18.3^{\circ} \mathrm{C}\right)$ to $75^{\circ} \mathrm{F}\left(23.9^{\circ} \mathrm{C}\right)$

Indoor air dry-bulb temperature $70 \mathrm{~F}\left(21.1^{\circ} \mathrm{C}\right)$ to $80^{\circ} \mathrm{F}\left(26.7^{\circ} \mathrm{C}\right)$

$50 \%$ of manufacturer's recommended refrigerant charge

1008 unit operation

24 hours total test duration

\section{Low refrigerant charge test (heating)}

Conditions same as 5 above, except entering water temperature $45^{\circ} \mathrm{F}$ $\left(7.2^{\circ} \mathrm{C}\right)$ to $55^{\circ} \mathrm{F}\left(1.28^{\circ} \mathrm{C}\right)$

\subsubsection{Life Cycle Reliability Tests}

Temperature tolerances for the reliability tests shall be as specified in performance requirements of the current applicable ARI standard. Voltage tolerances shall be \pm 3 volts. Supplemental heaters shall not be operated during any reliability tests.

\subsubsection{Criteria for Acceptance}

Criteria for acceptance shall be those of 6.3.1.1 with the addition that trip-out or similar operation of any manual-reset operating, protective, or limit control/device shall constitute a failure.

Additional criteria for acceptance for the Life Cycle Reliability Test option shall be compressor mean time between failures of at least 38,990 
hours of test time and system mean time between failures of at least 3,910 hours of test time, both for the 2,000 hour test cycle of section 6.3.2.2, with $80 \%$ confidence, assuming a constant failure rate. Reliability computations are to take all failures without any exceptions into account. A system failure is the occurrence of any condition which renders the heat pump system incapable of operating satisfactorily, within the specified performance limits, on a thermostat demand. A compressor failure constitutes a system failure requiring that the compressor be removed and replaced to restore satisfactory system operation.

The minimum number of units to be tested to meet the above $80 \%$ confidence criteria may be calculated by satisfying equation 6.1 or may be read from table 6.1 which lists the minimum number of units to be tested for various numbers of compressor failures and the maximum number of unit failures consistent with each listed test sample size.

$$
\sum_{x=0}^{n} \frac{e^{-m} m^{x}}{x !} \leq 0.2
$$

where $\mathrm{m}=\frac{\text { No. of units tested } * \text { No. of test hours per unit }}{\text { mean time between failure }}$

$$
\mathrm{n}=\text { Total number of failures allowed }
$$


Table 6.1 Minimum number of test units and maximum number of compressor failures and system failures required for life cycle reliability testing

Maximum Number of Compressor Failures
Minimum Number of Test Units
Maximum Number of Unit Failures
32

59

84

108

132
12

25

36

48

60

\subsubsection{Test Specifications}

1. High temperature test (cooling)

Outdoor air dry-bulb temperature $95^{\circ} \mathrm{F}\left(35.0^{\circ} \mathrm{C}\right)$ or higher

Indoor air dry-bulb temperature $70^{\circ} \mathrm{F}\left(21.1^{\circ} \mathrm{C}\right)$ to $80^{\circ} \mathrm{F}\left(26.7^{\circ} \mathrm{C}\right)$

Indoor relative humidity $50 \%$

Operation: off 15 minutes/on 15 minutes

Voltage $110 \%$ of specified, 350 hours duration

Voltage 908 of specified, 350 hours duration

\section{Defrost test (heating)}

Outdoor air dry-bulb temperature $38^{\circ} \mathrm{F}\left(3.3^{\circ} \mathrm{C}\right)$ to $32^{\circ} \mathrm{F}\left(0^{\circ} \mathrm{C}\right)$

Outdoor relative humidity $80 \%$

Indoor air dry-bulb temperature $70^{\circ} \mathrm{F}\left(21.1^{\circ} \mathrm{C}\right)$ to $80^{\circ} \mathrm{F}\left(26.7^{\circ} \mathrm{C}\right)$

Operation: off 10 minutes/on 10 minutes

800 hours duration

\section{Low temperature test (heating)}

Outdoor air dry-bulb temperature the higher of the local design temperature region or the unit cut-out temperature

Indoor air dry-bulb temperature $70^{\circ} \mathrm{F}\left(21.1^{\circ} \mathrm{C}\right)$ to $80^{\circ} \mathrm{F}\left(26.7^{\circ} \mathrm{C}\right)$

Operation: off 1 hour/on 1 hour

Voltage $110 \%$ of specified, 250 hours duration

Voltage $90 \%$ of specified, 250 hours duration

\subsubsection{Corrosion tests}

Under extreme climatic conditions at the application site, the purchaser may find it appropriate to require the heat pump outdoor and/or indoor unit to pass the following tests. 


\subsubsection{Salt Spray Test}

If a salt spray test is specified by the purchaser, portions of the heat pump that are normally exposed to the outdoor environment shall be tested in a corrosive environment as described in ASTM Bll7 (salt spray test). Unless otherwise specified in the contract or purchase order, the duration of this test shall be 240 hours.

\section{Salt-Spray test - ASTM Bll7 (cooling operation one hour at conclusion)}

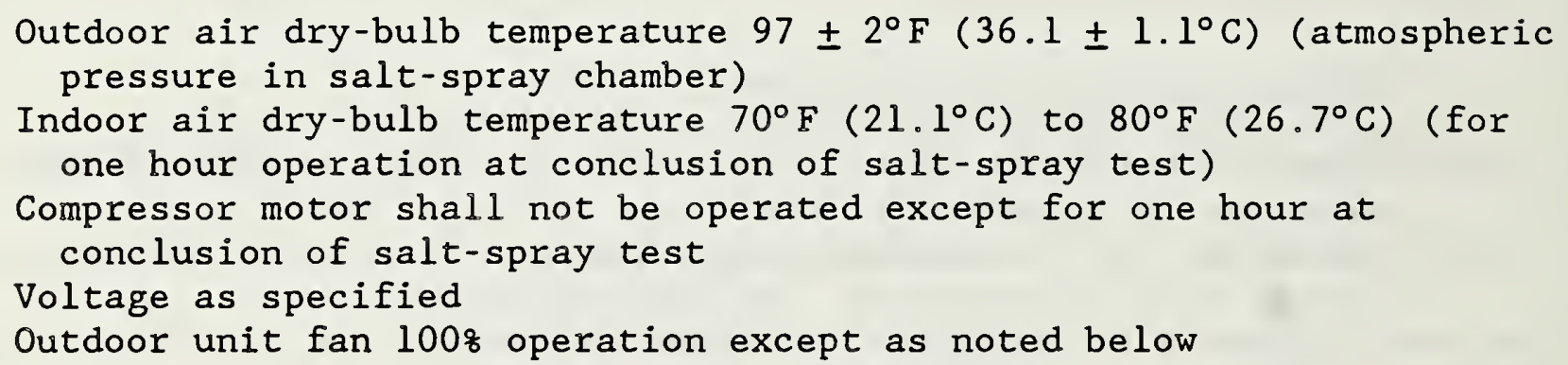

At the 24th and 96th hour of salt spray exposure, the heat pump fan and salt spray are turned off and the chamber door is left open for a period of 8 hours.

At the end of the 8 hour period the test is resumed.

At the conclusion of the final hour of actual salt-spray exposure, the spray shall be discontinued, the chamber door opened and the compressor turned on and operated in the cooling mode for one hour. Total duration of actual salt spray exposure shall be 240 hours (or 720 hours if specified in the contract or purchase order).

\subsubsection{Indoor Unit Corrosion Test}

If the 1008 relative humidity test is specified by the purchaser, the portions of the heat pump that are normally exposed to the indoor environment shall be tested as described in ASTM D2247 (100 percent relative humidity test). The time duration of this test shall be 240 hours. 
The extent of area of indoor and outdoor exposure to salt spray/humidity environment for corrosion testing of packaged (integral) type heat pumps shall be determined from size, dimension and construction considerations.

\author{
1008 Relative Humidity Test \\ Indoor air temperature $85 \mathrm{~F}(29.4 \mathrm{C})$ \\ Indoor fan operation $100 \%$ (no heating or cooling coil operation) \\ Voltage as specified \\ Interruption conditions at the 24 th and 96 th hour as specified in \\ test 7 above \\ 240 hours total $100 \%$ relative humidity exposure \\ Flaking, perforation, or penetration of metal parts shall be \\ considered a failure.
}

\title{
6.3.3.3 Criteria for Acceptance
}

Data to be taken before and after corrosion tests shall be recorded and results photographed as given in Section 3.3 of ASTM G33. For painted and all coated surfaces refer to ASTM D1654 for testing procedure where marks shall be scribed on vertical, horizontal, external and internal painted or coated surfaces. Rating Schedule No. 2 of ASTM D1654 shall be reported. The rating number shall not be less than 6 and there shall be no rust creep greater than $1 / 8^{\prime \prime}(3.2 \mathrm{~mm})$ normal to the scribe marks for acceptance. Blistering or flaking of paint or coating and rust creep at screw holes shall be reported and rated as above. Oxidation and corrosion of bare metal parts and at joints of dissimilar metals shall be reported and photographed. Flaking, perforation, or penetration of metal parts shall 
be considered failure. Impairing damage to any mechanical or electrical components shall be considered failure.

\section{LIFE CYCLE COST}

For purposes of this heat pump specification, the definition of the Life Cycle Cost (LCC) of a contract bid is given by the following expression:

$$
\mathrm{LCC}=\mathrm{C}+\mathrm{P} * \mathrm{~F} * \mathrm{E}
$$

where $\quad C=$ installed cost of the heat pump equipment based on the contract bid $(\$)$;

$P=$ current local unit price of electricity $(\$ / \mathrm{kWh}) ;$

$F=$ Modified Uniform Present Worth Factor, which takes into account the discount rate and the expected increases in electricity prices, and which assumes a fifteen year life for the heat pumps;

$E=$ total annual electric energy estimated to be consumed by the heat pump equipment for both heating and cooling ( $k$ Wh/year)

The first term, $C$, on the right-hand side of expression (1) represents the total dollar investment cost associated with installing the heat pump equipment specified in the contract. This cost should include acquisition, delivery, installation, start up, and initial testing of the heat pump equipment and of the associated controls and distribution system. This cost may be structured to include an initial or an extended period warranty for parts and/or labor. To assure that all of the contract bids 
are compared on an equal basis, the request for bids should specify the same warranty period to be offered by all the bidders. Comparability across bids also requires that the engineering specifications for the heat pump equipment be adequate to satisfy the heating and cooling loads of the target housing units specified in the request for bids. In this way, comparison of bids focuses on the effects of the only two variables still permitted to vary across bids: 1) the investment cost, C; and 2) the seasonal heating and cooling efficiency ratings used to compute total annual electric energy use, E.

The second term of expression (1), P, represents the current local unit price of electricity stated in $\$ / \mathrm{kWh}$. Given the objective of minimizing the LCC of supplying heating and cooling to housing on a particular military base, the theoretically correct value to be used for $P$ is the marginal cost savings that would result from reducing electricity consumption one $\mathrm{kWh}$ below the current level of consumption on the base. Data on current base consumption can be used to determine this marginal cost savings from the current rate schedule of the local utility. Alternatively, $P$ can be approximated by using the average price given in column (3) of Table 7-1 for the particular Department of Energy (DoE) Region in which the military base is located. For example, if the base were in Nevada, which is in DoE Region 9, the appropriate average price to use to approximate $P$ would be $\$ 0.072$ per $\mathrm{kWh}$. These average electricity prices for the various regions are derived from Tables $\mathrm{Ca}-1$ through $\mathrm{Ca}-11$ of a report issued annually in support of the Federal Energy Management Program of the 
Table 7-1. Average Electric Energy Price, P, and Modified Uniform Present Worth Factors, F, for the 10 DoE Regions and the United States Average for 1987

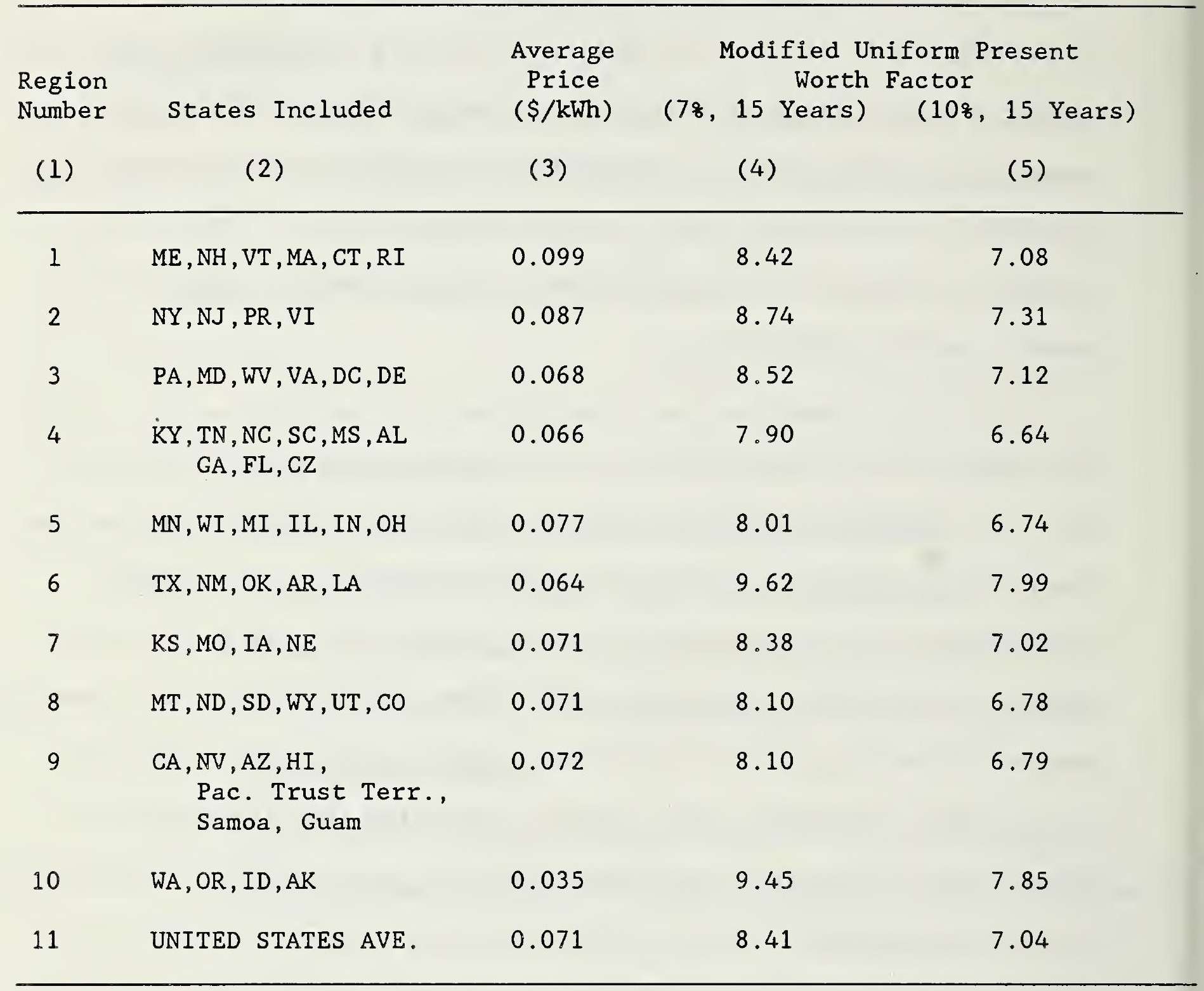

Source: Barbara C. Lippiatt and Rosalie T. Ruegg, "Energy Prices and Discount Factors for Life Cycle Cost Analysis: Annual Supplement to NBS Handbook 135 and NBS Special Publication 709, "NBSIR 853273-2 (Rev. 6/87) U.S. Dept. of Commerce, National Bureau of Standards, Gaithersburg, MD 20899. The prices given in the report in $\$ / m i l l i o n$ Btu were converted to $\$ / k W h$ by assuming 3413 $\mathrm{Btu} / \mathrm{kWh}$. 
Department of Energy. ${ }^{1}$ The prices specifically refer to electricity supplied to the commercial sector in 1987. Updates are available on an annual basis from the DoE Federal Energy Management Program.

The term $F$ in expression (1) represents the Modified Uniform Present Worth Factor that converts a future stream of variable annual cash payments to its equivalent present value. This factor is designed to take into account three elements: (1) the discount rate, (2) the duration of the cash payments, and (3) variations in the annual cash payments that may result from electricity price fluctuations. The discount rate is the rate of interest that reflects the decision maker's time value of money. For evaluating energy conservation investments made by Federal agencies, the Energy Security Act of 1980 (P.L. 96-294) requires that a discount rate of 7 percent be used. ${ }^{2}$ For evaluating Federal investments that are not primarily intended to conserve energy, the U.S. Office of Management and Budget requires that a discount rate of 10 percent be used (except for a few types of investments such as for water resources and capital asset leasing.) $)^{3}$ Thus, if the heat pump procurement is being undertaken primarily to conserve energy, the 7 percent discount rate should be used; otherwise, the 10 percent discount rate should be used.

${ }^{1}$ Barbara C.Lippiatt and Rosalie T.Ruegg, "Energy Prices and Discount Factors for Life Cycle Cost Analysis: Annual Supplement to NBS Handbook 135 and NBS Special Publication 709," NBSIR 85-3273-2 (Rev. 6/87) U.S. Dept. of Commerce, National Bureau of Standards, Gaithersburg, MD 20899.

${ }^{2}$ Energy Security Act, P.L. 96-294, 94 STAT 611, sec. 405 (1980).

${ }^{3}$ U.S. Office of Management and Budget, "Discount Rates to be Used in Evaluating Time-Distributed Costs and Benefits," (Washington, DC: U.S. Office of Management and Budget, Circular A-94, March 27, 1972). 
The second element affecting the value of $F$, the duration of the cash payments, is determined by the expected service life of the heat pump equipment being installed. This specification assumes that the service life of every heat pump alternative being proposed is the same 15 year period.

The third element that determines the appropriate value of $F$ in expression (1) is the expected price of electricity during the 15 year life of the equipment. The DoE Energy Information Administration provides projections of electricity prices. These projections serve as the basis for the computed $F$ values published in Tables.B-1a through B-11a and B-1b through B-11b of "Energy Prices and Discount Factors for Life-Cycle Cost Analysis," referenced above. The $F$ values in these tables cover a range of study periods for both 7 and 10 percent discount rates. Table 7-1 presents these F values for a study period of 15 years for each of the 10 DoE regions and the United States Average in Columns (4) and (5).

The final term in expression (1) is $\mathrm{E}$ and represents the total annual electricity estimated to be consumed by the heat pump for an entire year of heating and cooling. The value of $E$ for each contract proposal is determined by separately estimating annual electricity consumption for the cooling season and for the heating season and then summing the two estimates.

The procedure for calculating $\mathrm{E}$ shall be one which qualifies as an acceptable evaluation technique under the U.S. Department of Energy's Building Energy Performance Standards. The method of DoE/NBS-0011 is recommended. The heat pump efficiencies to be used in this calculation 
shall be the manufacturers' values for SEER for the cooling season and HSPF for the heating season of the DoE region in which the installation site lies. For water source units that do not require resistance heat to meet the building load, the SEER and the HSPF shall be equal to their respective steady-state efficiencies for the local seasonal average ground water temperature times a factor of 0.9 in the cooling mode and 0.85 in the heating mode to take into account cyclic degradation. If resistance heat is required to meet the building load with a water source unit the HSPF shall be calculated by a bin calculation on which the steady-state efficiency shall be degraded by a constant part load factor of 0.85 in all bins. When published, a DoE method for water source units shall replace this method.

\section{REQUIREMENTS FOR QUALIFIED INSTALLER}

\subsection{Qualification}

Dealer/Installer shall be certified by the heat pump manufacturer as having his senior mechanics successfully passed their factory sponsored installation course in the past ten years. The Dealer/Installer shall be local; that is, the military base shall lie within his normal radius of service. Dealer/Installer shall guarantee that his installation and charging method is completely in accordance with the manufacturer's procedures and provide a demonstration of the procedure on site.

\subsection{Guarantee}

Dealer/Installer shall provide a five year service contract guaranteeing normal preventative maintenance as well as parts and labor for repairs. This contract shall offer the first year all parts and labor free of charge 
and service contract for the next four years, the cost of which shall be included in item $C$ of equation (1) in Section 7. 
NBS.114A (REV. 2.8C)

U.S. DEPT. OF COMM. BIBLIOGRAPHIC DATA

SHEET (See instruction s)

1. PUBLICATION OR REPORT NO.

NBSIR 88 -3805
2. Performing Organ. Report No. 3. Publication Date

JUNE 1983

4. TITLE AND SUBTITLE

Revised Unitary Heat Pump Specification for Military Family Housing

5. $\operatorname{AUTHOR}(S)$

William Mulroy, Stephen Weber, David Didion

6. PERFORMING ORGANIZATION (If joint or other than NBS, see instructions)

NATIONAL BUREAU OF STANDARDS

DEPARTMENT OF COMMERCE

WASHINGTON, D.C. 20234

9. SPONSORING ORGANIZATION NAME AND COMPLETE ADDRESS (Street, City. Stote, ZIP)

7. Contract/Grant No.

Army Corps of Engineers Engineering Services and

Department of the Army

Utility Branch

Naval Facilities Engineering Command

Washington, D.C. 20314 Department of the Air Force

Department of the Navy

Washington, D.C. 20330-5000

Alexandria, Virginia 22332

10. SUPPLEMENTARY NOTES

Document describes a computer program; SF-185, FIPS Software Summary, is attached.

11. ABSTRACT (A 200-word or less factual summary of most significant information. If document includes a significant bibliogrophy or literature survey. mention it here)

The purpose of this report is to revise and update the unitary heat pump specifications developed in 1976* which addressed the requirements for performance, testing, rating, design, safety, serviceability and reliability for the system and components; and conformance conditions. The document is intended for guidance in military procurement and applies to hermetic electrically-driven vapor compression unitary heat pumps of the remote (split) and packaged (integral) types, the air-to-air and water-to-water classes, and sizes from 12,000 to $135,000 \mathrm{Btu} / \mathrm{h}$ for both heating and cooling functions. This report reflects changes in specifications such that the qualified units would be compatible with current available commercial products. It also addresses installation practices and offers a new life cycle costing criteria for competitive selection.

It is written in the format of a draft specification.

12. KEY WORDS (Six to twelve entries; alphobetical order; copitalize only proper nomes; ond seporate key words by semicolons) heating and cooling; military family housing; specifications; unitary heat pump

13. AVAILABILITY

[X] Unlimited

For Official Distribution. Do Not Release to NTIS

Order From Superintendent of Documents, U.S. Government Printing Office, Washington, D.C. 20402.

X. Order From National Technical Information Service (NTIS), Springfield, VA. 22161
14. NO. OF

PRINTED PAGES

48

15. Price

$\$ 11.95$ 





